\title{
BIOLOGICAL PARAMETERS OF Spodoptera frugiperda (J.E. SMITH) (LEPIDOPTERA: NOCTUIDAE) ASSAYED WITH Bacillus thuringiensis BERLINER
}

\author{
Ricardo Antonio Polanczyk ${ }^{1 *}$; Sérgio Batista Alves² \\ ${ }^{1}$ UFES/CCA - Depto. de Fitotecnia, C.P. 16 - 29500-000 - Alegre, ES - Brasil. \\ ${ }^{2}$ USP/ESALQ - Depto. de Entomologia, Fitopatologia e Zoologia Agrícola, C.P. 9 - 13418-900 - Piracicaba, SP - \\ Brasil. \\ *Corresponding author <ricardo@cca.ufes.br>
}

\begin{abstract}
The bacterium Bacillus thuringiensis $(B t)$ is a promising control agent of Spodoptera frugiperda (J.E. Smith). Besides the lethal effect on hosts, the entomopathogen may cause physiological alterations that hinder insects' feeding intake and reproduction. Larval and female pupa weight, oviposition and egg fecundity were determined in second instar $S$. frugiperda larvae infected with $39 \mathrm{Bt}$ isolates in four bioassays. Sublethal effects were observed in the follow isolates: ESALQ 1.1, ESALQ 1.4, ESALQ 1.6, ESALQ 3.7, ESALQ 4.2 and ESALQ 5.2 (larval and female pupae weight); ESALQ 5.1 (larval weight); ESALQ 1.2 and ESALQ 3.7 (egg fecundity); ESALQ 3.7 (oviposition and egg fecundity); ESALQ 3.7 and ESALQ 5.2 (oviposition). Significant correlations were observed when parameters were analyzed together, except in the second bioassay (female pupal weight $\times$ oviposition, female pupal weight $\times$ egg fecundity and oviposition $\times$ egg fecundity). Some $B t$ isolates affected the biological parameters of $S$. frugiperda, mainly larval and female pupae weight, and in some instances these effects were passed on to further life cycle stages affecting oviposition and egg fecundity. Although sublethal effects are difficult to evaluate, mainly under field conditions, they should be considered when the activity of an entomopathogen is measured.
\end{abstract}

Key words: entomopathogen, fall armyworm, sublethal effects

\section{PARÂMETROS BIOLÓGICOS DE Spodoptera frugiperda (J.E. SMITH) (LEPIDOPTERA: NOCTUIDAE) SOB EFEITO DE Bacillus thuringiensis BERLINER}

\begin{abstract}
RESUMO: A bactéria Bacillus thuringiensis (Bt) é um promissor agente de controle de Spodoptera frugiperda (J.E. Smith). Além do efeito letal sobre os hospedeiros, os entomopatógenos podem causar alterações fisiológicas que comprometem o desenvolvimento dos insetos, podendo chegar a ponto de prejudicar a alimentação e/ou reprodução. No presente estudo, quatro bioensaios em laboratório foram realizados para verificar os efeitos subletais de isolados de $B t$ sobre os parâmetros biológicos de lagartas de segundo ínstar de S. frugiperda. A atividade de 39 isolados foi avaliada pelo peso de lagartas e de pupas fêmeas, oviposição e fecundidade de ovos de insetos sobreviventes. Foram observados efeitos subletais sobre as lagartas nos seguintes isolados: ESALQ 1.1, ESALQ 1.4, ESALQ 1.6, ESALQ 3.7, ESALQ 4.2 e ESALQ 5.2 (peso de lagartas e pupas fêmeas); ESALQ 5.1 (peso de lagartas); ESALQ 1.2 e ESALQ 3.7 (fecundidade dos ovos); ESALQ 3.7 (oviposição e fecundidade dos ovos) e ESALQ 3.7 e ESALQ 5.2 (oviposição). Quando os parâmetros foram analisados juntos, foram observadas correlações significativas entre eles, exceto no segundo bioensaio (peso de pupas fêmeas $\times$ oviposição, peso de pupas fêmeas $\times$ fecundidade dos ovos e oviposição $\times$ fecundidade dos ovos). Alguns isolados de $B t$ afetaram os parâmetros biológicos, principalmente peso de larvas e pupas fêmeas e, em alguns casos esses efeitos passaram para estágios posteriores do ciclo do inseto, afetando a oviposição e a viabilidade dos ovos. Embora, esses efeitos sejam difíceis de avaliar, especialmente em campo, eles deveriam ser considerados quando a atividade de um entomopatógeno é avaliada.

Palavras-chave: entomopatógeno, lagarta-do-cartucho, efeitos subletais
\end{abstract}

\section{INTRODUCTION}

Some Gram-positive bacteria bring important benefits to vertebrates physiology, like improvment in feed digestion, and others have great potential in biological control programs (Priest, 2000). The entomopathogenic bacterium Bacillus thuringiensis (Bt), is rod-shaped, spore forming and capable of producing large crystal protein inclusions during sporulation, which are mainly responsible for the insecticidal properties of this microorganism (Glare \& O'Callagham, 2000).

$B t$ is the most successful pathogen sold worldwide. $B t$ formulations account for about $90 \%$ of all biopesticides in the market. North America and Canada accounts for 
Table 1- Sublethal effects of Bacillus thuringiensis isolates to larvae and female pupae weight (grams) of Spodoptera frugiperda.

\begin{tabular}{|c|c|c|c|}
\hline Treatments & Larvae & Treatments & Pupae \\
\hline & $\mathrm{g}$ & & $\mathrm{g}$ \\
\hline \multicolumn{4}{|c|}{ Biossay 1} \\
\hline ESALQ 2.3 & $0.3159 \pm 0.017 \mathrm{a}$ & Control & $0.2424 \pm 0.002 \mathrm{a}$ \\
\hline ESALQ 2.2 & $0.3094 \pm 0.005 \mathrm{ab}$ & ESALQ 2.2 & $0.2255 \pm 0.012 \mathrm{ab}$ \\
\hline Control & $0.2917 \pm 0.003 \mathrm{abc}$ & ESALQ 2.3 & $0.2254 \pm 0.009 \mathrm{ab}$ \\
\hline ESALQ 1.3 & $0.2758 \pm 0.015 \mathrm{abc}$ & ESALQ 1.1 & $0.2106 \pm 0.005 \mathrm{ab}$ \\
\hline ESALQ 1.2 & $0.2668 \pm 0.003 \mathrm{bc}$ & ESALQ 1.6 & $0.2071 \pm 0.004 \mathrm{ab}$ \\
\hline ESALQ 1.5 & $0.2635 \pm 0.006 \quad b c$ & ESALQ 2.1 & $0.2038 \pm 0.008 \mathrm{ab}$ \\
\hline ESALQ 2.1 & $0.2632 \pm 0.006 \quad \mathrm{bc}$ & ESALQ 1.5 & $0.2037 \pm 0.007 \mathrm{ab}$ \\
\hline ESALQ 1.4 & $0.2524 \pm 0.010 \quad \mathrm{c}$ & ESALQ 1.4 & $0.1994 \pm 0.012 b$ \\
\hline ESALQ 1.6 & $0.2506 \pm 0.008 \quad \mathrm{c}$ & ESALQ 1.3 & $0.1925 \pm 0.004 \quad b$ \\
\hline ESALQ 1.1 & $0.2480 \pm 0.006$ & ESALQ 1.2 & $0.1913 \pm 0.009 \quad b$ \\
\hline \multicolumn{4}{|c|}{ Biossay 2} \\
\hline Control & $0.3293 \pm 0.008 \mathrm{a}$ & ESALQ 2.9 & $0.2512 \pm 0.013 \mathrm{a}$ \\
\hline ESALQ 2.7 & $0.3289 \pm 0.109 \mathrm{a}$ & ESALQ 2.8 & $0.2453 \pm 0.011 \mathrm{a}$ \\
\hline ESALQ 2.9 & $0.3248 \pm 0.026 \mathrm{a}$ & ESALQ 3.3 & $0.2383 \pm 0.008 \mathrm{a}$ \\
\hline ESALQ 2.8 & $0.3185 \pm 0.009 \mathrm{a}$ & Control & $0.2381 \pm 0.005 \mathrm{a}$ \\
\hline ESALQ 2.5 & $0.3160 \pm 0.005 \mathrm{a}$ & ESALQ 3.4 & $0.2333 \pm 0.006 \mathrm{a}$ \\
\hline ESALQ 2.6 & $0.3150 \pm 0.015 \mathrm{a}$ & ESALQ 3.1 & $0.3201 \pm 0.007 \mathrm{a}$ \\
\hline ESALQ 2.4 & $0.3067 \pm 0.007 \mathrm{a}$ & ESALQ 2.4 & $0.2208 \pm 0.010 \mathrm{a}$ \\
\hline ESALQ 3.3 & $0.3038 \pm 0.017 \mathrm{a}$ & ESALQ 2.5 & $0.2191 \pm 0.007 \mathrm{a}$ \\
\hline ESALQ 3.2 & $0.3019 \pm 0.023 a$ & ESALQ 2.7 & $0.2172 \pm 0.016 \mathrm{a}$ \\
\hline ESALQ 3.1 & $0.3015 \pm 0.032 \mathrm{a}$ & ESALQ 3.2 & $0.2120 \pm 0.008 \mathrm{a}$ \\
\hline ESALQ 3.4 & $0.2945 \pm 0.010 \mathrm{a}$ & ESALQ 2.6 & $0.1496 \pm 0.074 \mathrm{a}$ \\
\hline \multicolumn{4}{|c|}{ Biossay 3} \\
\hline Control & $0.2979 \pm 0.017 \mathrm{a}$ & ESALQ 3.12 & $0.2408 \pm 0.177 \mathrm{a}$ \\
\hline ESALQ 3.8 & $0.2858 \pm 0.001 \mathrm{a}$ & ESALQ 3.8 & $0.2318 \pm 0.010 \mathrm{a}$ \\
\hline ESALQ 3.12 & $0.2857 \pm 0.004 \mathrm{a}$ & ESALQ 3.6 & $0.2315 \pm 0.009 a$ \\
\hline ESALQ 3.6 & $0.2918 \pm 0.014 \mathrm{a}$ & ESALQ 3.5 & $0.2298 \pm 0.013 \mathrm{a}$ \\
\hline ESALQ 3.5 & $0.2890 \pm 0.005 a$ & Control & $0.2274 \pm 0.006 \mathrm{a}$ \\
\hline ESALQ 3.10 & $0.2877 \pm 0.013 \mathrm{a}$ & ESALQ 3.9 & $0.2263 \pm 0.004 \mathrm{a}$ \\
\hline ESALQ 3.11 & $0.2819 \pm 0.013 \mathrm{a}$ & ESALQ 3.11 & $0.2221 \pm 0.006 \mathrm{a}$ \\
\hline ESALQ 3.13 & $0.2638 \pm 0.002 \mathrm{a}$ & ESALQ 3.13 & $0.2186 \pm 0.008 \mathrm{a}$ \\
\hline ESALQ 3.9 & $0.2625 \pm 0.008 \mathrm{a}$ & ESALQ 3.10 & $0.2164 \pm 0.016 \mathrm{a}$ \\
\hline ESALQ 4.1 & $0.2610 \pm 0.003 \mathrm{a}$ & ESALQ 4.1 & $0.2159 \pm 0.003 \mathrm{a}$ \\
\hline ESALQ 3.7 & $0.1734 \pm 0.004 \quad b$ & ESALQ 3.7 & $0.0852 \pm 0.001 \quad b$ \\
\hline \multicolumn{4}{|c|}{ Biossay 4} \\
\hline ESALQ 4.8 & $0.3261 \pm 0.014 \mathrm{a}$ & ESALQ 4.5 & $0.2338 \pm 0.011 \mathrm{a}$ \\
\hline ESALQ 4.7 & $0.3192 \pm 0.020 \mathrm{a}$ & ESALQ 4.8 & $0.2308 \pm 0.002 \mathrm{a}$ \\
\hline ESALQ 4.6 & $0.3129 \pm 0.019 \mathrm{a}$ & ESALQ 4.7 & $0.2204 \pm 0.004 \mathrm{ab}$ \\
\hline Control & $0.3107 \pm 0.032 \mathrm{a}$ & ESALQ 4.3 & $0.2174 \pm 0.002 \mathrm{ab}$ \\
\hline ESALQ 4.5 & $0.3015 \pm 0.004 \mathrm{a}$ & ESALQ 4.9 & $0.2128 \pm 0.008 \mathrm{ab}$ \\
\hline ESALQ 4.4 & $0.2860 \pm 0.007 \mathrm{a}$ & Control & $0.2085 \pm 0.015 \mathrm{ab}$ \\
\hline ESALQ 4.3 & $0.2810 \pm 0.003 \mathrm{a}$ & ESALQ 4.6 & $0.2073 \pm 0.011 \mathrm{ab}$ \\
\hline ESALQ 4.9 & $0.2585 \pm 0.008 \mathrm{ab}$ & ESALQ 4.4 & $0.2036 \pm 0.002 \mathrm{ab}$ \\
\hline ESALQ 5.1 & $0.2033 \pm 0.013 \quad b$ & ESALQ 5.1 & $0.1902 \pm 0.006 \mathrm{~b}$ \\
\hline ESALQ 4.2 & $0.1850 \pm 0.003 \quad \mathrm{c}$ & ESALQ 4.2 & $0.1268 \pm 0.004 \quad \mathrm{c}$ \\
\hline ESALQ 5.2 & $0.1624 \pm 0.002$ & ESALQ 5.2 & $0.1080 \pm 0.002 \quad \mathrm{c}$ \\
\hline
\end{tabular}

Column means ( \pm Standard error) followed by the same letters in each bioassay do not differ $(P=0.05)$.

Sci. Agric. (Piracicaba, Braz.), v.62, n.5, p.464-468, Sept./Oct. 2005 
$50 \%$ of the market share and Latin America represents about 8 to $10 \%$ of the total (Tamez-Guerra et al., 2001). Hansen \& Salamitou (2000) estimated the annual worldwide $B t$ production to be approximately 13,000 tons.

The screening of isolates with high virulence is the most important step in the biopesticides development. Pathogen pathogenicity and virulence are the most frequently evaluated parameters, although sublethal effects on surviving hosts should be also considered, for instance, insects not dying by pathogen-insect interaction but may have their physiological processes affected resulting in harmeless larvae.

Few studies evaluated the sublethal effects of $B t$ on larvae (Abdul-Sattar \& Watson, 1982; Pedersen et al., 1997; Salama et al., 1981 and Salama \& Sharaby, 1988) due to difficulties to evaluate these parameters under field conditions. This work evaluated the effects of $B t$ isolates on larval and female pupae weight, oviposition and egg fecundity parameters in Spodoptera frugiperda larvae.

\section{MATERIAL AND METHODS}

An initial population of 120 to 150 insects were collected in corn fields occasionally sprayed with pesticides. Insects were raised for six generations in the laboratory before being bioassayed, to avoid genetic drift, selection, and inbreeding (Boller \& Chambers, 1977). Larvae were fed with an artificial diet (Burton $\&$ Perkins, 1972) and adults were fed with a $10 \%$ sugar solution.

A set of $39 \mathrm{Bt}$ isolates belonging to the Collection of Entomopathogens from Piracicaba, SP, were assayed in four bioassays against the fall armyworm. These $B t$ strains were grown in BHI medium (Brain and Hearth Infusion $-\mathrm{BHI}$ Broth), at $28^{\circ} \mathrm{C}$ and $120 \times \mathrm{g}$ for 76 hours to get a constant bacterial growth. After bacterial lysis, the solution containing spores, crystals, and vegetative cells were centrifuged and the pellets washed three times $(3,600 \times \mathrm{g}$ for 20 minutes) to eliminate extracellular toxins, e.g. $\beta$-exotoxins in the medium. After this procedure, a $1 \mathrm{~mL}$ pellet aliquot was diluted 1,000 times in distilled water and spore concentration $\left(3 \times 10^{8}\right.$ spores + crystals $\mathrm{mL}^{-1}$ ) was determined using a Petroff-Hauser chamber (Alves \& Moraes, 1998).

One hundred microlliters of $B t$ suspension were added at the surface of the artificial diet (Burton \& Perkins, 1972) into Petri plates $(2.5 \times 1.0 \mathrm{~cm})$. The amount of diet used was enough to allow insect development and uniform $B t$ suspension and distribution. After excess water evaporation, 45 second instar larvae (three replicates), were placed in the recipients. Equal amounts of water were added to the control. Recipients were acconditionated in B.O.D. chamber at $25 \pm 0.5^{\circ} \mathrm{C}$, $65 \pm 10 \%$ RU, and 12 hours of light. Observations were made in a dayly basis until the $7^{\text {th }}$ day of incubation.
Dead larvae were recorded (data not shown) and live larvae were evaluated until larval weight (nine days after treatment application), female pupae weight (one day after pupation), oviposition and egg fecundity. To evaluate the female oviposition capability, 18 insect couples were mated per treatment. Egg counting was recorded in the $3^{\text {rd }}$ day after mating, according to the method proposed by Leuck \& Perkins (1972). The parameters were compared among treatments by the Tukey test $(\alpha=0.05)$ and correlation analyses were used to test the associations among the parameters.

\section{RESULTS AND DISCUSSION}

Pupal weight in ESALQ 1.1, ESALQ 1.4, and ESALQ 1.6 isolates was lower $(P<0.05)$ than control treatment in the first biossay. Only pupae weight on isolate ESALQ 3.7 was lower than control treatment on biossay three. The same was observed in the last bioassay regarding ESALQ 4.2, ESALQ 5.1, ESALQ 5.2 (larval weight) and ESALQ 4.2 and ESALQ 5.2 (pupae weight) (Table 1).

The correlation analyses showed that in all experiments but the second, there was correlation between larvae and female pupae weight, indicating an associaton between these parameters, i.e. the larvae physiology was affected in a such way that reduced the pupae weight (Table 2). Due to the relation between female pupae weight and oviposition (Boller \& Chambers, 1977) it is expected that these insects would lay less eggs than the healthy ones.

No effect on insects (pupae weight, oviposition, and egg fecundity) was observed at the first bioassay, but the isolate ESALQ 1.2 influenced egg viability and ovipositon. ESALQ 3.7 isolate affected both characteristics at the third bioassay (Table 3).

Significant correlations were observed in all bioassays (Table 4), but the second. Some isolates affected the adult physiology in a such way that reflected in the quality and amount of eggs layed. Similar results were reported by Abdul-Sattar \& Watson (1982) who recorded that Bt affected the mating behavior and oviposition of $H$. virescens, with the eggs hatching close to zero.

Table 2 - Linear correlation (r) between larvae and female pupae weight of Spodoptera frugiperda that survived to Bacillus thuringiensis inoculation.

\begin{tabular}{lcl}
\hline Bioassay & rVALUE & \multicolumn{1}{c}{$\mathrm{P}>\mathrm{t}$} \\
\hline 1 & 0.36 & $0.04748^{*}$ \\
2 & -0.32 & 0.07774 \\
3 & 0.70 & $0.00004^{*}$ \\
4 & 0.73 & $0.00001^{*}$ \\
\hline
\end{tabular}

*Significant $(P<0.05)$ 
Table 3 - Bacillus thuringiensis effect on female pupae weight, oviposition and egg fecundity of Spodoptera frugiperda.

\begin{tabular}{|c|c|c|c|}
\hline \multirow{2}{*}{$\begin{array}{l}\text { Parameters } \\
\text { Treatments }\end{array}$} & Female pupae weight & Oviposition & Egg fecundity \\
\hline & g* & number of eggs $* *$ & $\% *$ \\
\hline \multicolumn{4}{|c|}{ Bioassay 1} \\
\hline ESALQ 1.1 & $0.2106 \pm 0.005$ & $139.19 \pm 12.06 \mathrm{ab}$ & $52.59 \pm 10.20 \mathrm{a}$ \\
\hline ESALQ 1.2 & $0.1913 \pm 0.009$ & $52.40 \pm 18.05 \quad \mathrm{c}$ & $07.00 \pm 3.00 \mathrm{~b}$ \\
\hline ESALQ 1.3 & $0.1925 \pm 0.004$ & $127.40 \pm 29.93 \mathrm{ab}$ & $49.20 \pm 12.37 \mathrm{a}$ \\
\hline ESALQ 1.4 & $0.1994 \pm 0.012$ & $142.20 \pm 12.39 \mathrm{a}$ & $55.00 \pm 9.15 \mathrm{a}$ \\
\hline ESALQ 1.5 & $0.2037 \pm 0.007$ & $107.80 \pm 15.63 \mathrm{ab}$ & $48.20 \pm 6.39 \mathrm{a}$ \\
\hline ESALQ 1.6 & $0.2071 \pm 0.004$ & $133.80 \pm 12.00 \mathrm{ab}$ & $59.00 \pm 4.74 \mathrm{a}$ \\
\hline ESALQ 2.1 & $0.2038 \pm 0.008$ & $133.60 \pm 12.79 \mathrm{a}$ & $48.40 \pm 11.73 \mathrm{a}$ \\
\hline ESALQ 2.2 & $0.2255 \pm 0.012$ & $127.00 \pm 12.88 \mathrm{ab}$ & $49.20 \pm 5.08 \mathrm{a}$ \\
\hline ESALQ 2.3 & $0.2254 \pm 0.009$ & $154.60 \pm 6.45 \mathrm{ab}$ & $57.00 \pm 7.19 \mathrm{a}$ \\
\hline Control & $0.2424 \pm 0.002$ & $133.20 \pm 7.93 \mathrm{ab}$ & $54.00 \pm 5.22 \mathrm{a}$ \\
\hline \multicolumn{4}{|c|}{ Bioassay 2} \\
\hline ESALQ 2.4 & $0.2208 \pm 0.010$ & $108.20 \pm 13.60 \mathrm{a}$ & $55.00 \pm 12.70 \mathrm{a}$ \\
\hline ESALQ 2.5 & $0.2333 \pm 0.006$ & $109.00 \pm 10.85 \mathrm{a}$ & $30.79 \pm 4.70 \mathrm{a}$ \\
\hline ESALQ 2.6 & $0.3201 \pm 0.007$ & $123.59 \pm 19.44 \mathrm{a}$ & $46.20 \pm 7.01 \mathrm{a}$ \\
\hline ESALQ 2.7 & $0.2453 \pm 0.011$ & $117.80 \pm 13.59 \mathrm{a}$ & $44.00 \pm 4.70 \mathrm{a}$ \\
\hline ESALQ 2.8 & $0.2453 \pm 0.011$ & $114.80 \pm 10.07 \mathrm{a}$ & $48.20 \pm 6.39 \mathrm{a}$ \\
\hline ESALQ 2.9 & $0.2512 \pm 0.013$ & $107.80 \pm 6.98 \mathrm{a}$ & $39.20 \pm 4.20 \mathrm{a}$ \\
\hline ESALQ 3.1 & $0.2120 \pm 0.008$ & $116.80 \pm 24.44 \mathrm{a}$ & $47.90 \pm 3.51 \mathrm{a}$ \\
\hline ESALQ 3.2 & $0.2120 \pm 0.008$ & $136.40 \pm 5.60 \mathrm{a}$ & $50.40 \pm 3.41 \mathrm{a}$ \\
\hline ESALQ 3.3 & $0.2191 \pm 0.007$ & $122.80 \pm 18.16 \mathrm{a}$ & $47.00 \pm 5.45 \mathrm{a}$ \\
\hline ESALQ 3.4 & $0.1496 \pm 0.074$ & $126.80 \pm 9.85 \mathrm{a}$ & $53.80 \pm 8.19 \mathrm{a}$ \\
\hline Chack treatment & $0.2381 \pm 0.005$ & $139.20 \pm 10.52 \mathrm{a}$ & $50.00 \pm 4.47 \mathrm{a}$ \\
\hline \multicolumn{4}{|c|}{ Bioassay 3} \\
\hline ESALQ 3.5 & $0.2298 \pm 0.013$ & $101.59 \pm 13.23 \mathrm{ab}$ & $54.00 \pm 7.14 \mathrm{a}$ \\
\hline ESALQ 3.6 & $0.2315 \pm 0.009$ & $120.60 \pm 09.79 a b$ & $48.60 \pm 7.25 \mathrm{a}$ \\
\hline ESALQ 3.7 & $0.0852 \pm 0.001$ & $23.00 \pm 11.64 \quad c$ & $4.00 \pm 1.87 b$ \\
\hline ESALQ 3.8 & $0.2318 \pm 0.010$ & $125.60 \pm 05.98 \mathrm{ab}$ & $47.20 \pm 5.76 \mathrm{a}$ \\
\hline ESALQ 3.9 & $0.2263 \pm 0.004$ & $138.00 \pm 15.31 \mathrm{ab}$ & $51.60 \pm 3.24 \mathrm{a}$ \\
\hline ESALQ 3.10 & $0.2263 \pm 0.004$ & $129.60 \pm 13.02 \mathrm{ab}$ & $48.60 \pm 3.82 \mathrm{a}$ \\
\hline ESALQ 3.11 & $0.2221 \pm 0.006$ & $115.00 \pm 10.77 \mathrm{ab}$ & $42.40 \pm 4.63 \mathrm{a}$ \\
\hline ESALQ 3.12 & $0.2408 \pm 0.177$ & $96.59 \pm 19.34 \quad b c$ & $27.80 \pm 6.12 \mathrm{ab}$ \\
\hline ESALQ 3.13 & $0.2186 \pm 0.008$ & $156.40 \pm 07.66 \mathrm{a}$ & $43.40 \pm 14.85 \mathrm{a}$ \\
\hline ESALQ 4.1 & $0.2159 \pm 0.003$ & $123.20 \pm 09.04 \mathrm{ab}$ & $49.20 \pm 4.04 \mathrm{a}$ \\
\hline Control & $0.2274 \pm 0.006$ & $137.20 \pm 04.69 \mathrm{ab}$ & $52.20 \pm 7.17 \mathrm{a}$ \\
\hline \multicolumn{4}{|c|}{ Bioassay 4} \\
\hline ESALQ 4.2 & $0.1268 \pm 0.004$ & $69.80 \pm 10.08 \mathrm{ab}$ & $27.60 \pm 4.91 \mathrm{ab}$ \\
\hline ESALQ 4.3 & $0.2174 \pm 0.002$ & $121.59 \pm 21.02 \mathrm{a}$ & $59.60 \pm 3.55 \mathrm{a}$ \\
\hline ESALQ 4.4 & $0.2036 \pm 0.002$ & $127.40 \pm 29.93 \mathrm{a}$ & $40.00 \pm 7.04 \mathrm{ab}$ \\
\hline ESALQ 4.5 & $0.2338 \pm 0.011$ & $133.00 \pm 10.60 \mathrm{a}$ & $40.60 \pm 5.50 \mathrm{ab}$ \\
\hline ESALQ 4.6 & $0.2204 \pm 0.004$ & $122.80 \pm 07.74 \mathrm{a}$ & $49.20 \pm 6.01 \mathrm{ab}$ \\
\hline ESALQ 4.7 & $0.2204 \pm 0.004$ & $129.80 \pm 13.79 \mathrm{a}$ & $45.20 \pm 4.50 \mathrm{ab}$ \\
\hline ESALQ 4.8 & $0.2308 \pm 0.002$ & $126.00 \pm 05.18 \mathrm{a}$ & $44.60 \pm 3.85 \mathrm{ab}$ \\
\hline ESALQ 4.9 & $0.2128 \pm 0.008$ & $138.00 \pm 11.83 \mathrm{a}$ & $46.20 \pm 4.21 \mathrm{ab}$ \\
\hline ESALQ 5.1 & $0.1902 \pm 0.006$ & $112.60 \pm 13.68 \mathrm{ab}$ & $47.80 \pm 6.03 \mathrm{ab}$ \\
\hline ESALQ 5.2 & $0.1080 \pm 0.002$ & $46.00 \pm 19.15 \mathrm{~b}$ & $22.80 \pm 6.97 \mathrm{~b}$ \\
\hline Control & $0.2085 \pm 0.015$ & $127.19 \pm 06.00 \mathrm{a}$ & $48.40 \pm 7.60 \mathrm{ab}$ \\
\hline
\end{tabular}

*Mean treatments **egg number \pm standard error ${ }^{1}$ from Table 1.

Means $( \pm \mathrm{SE})$ followed by the same letters in the column for each bioassay do not differ. $(P=0.05)$ 
Table 4 - Linear correlation analyses (r), between female pupae weight, oviposition and egg fecundity of Spodoptera frugiperda that survived to Bacillus thuringiensis inoculation.

\begin{tabular}{|c|c|c|}
\hline Bioassays / evaluated parameters & r Value & $\mathrm{P}>\mathrm{bt}$ \\
\hline \multicolumn{3}{|l|}{ Bioassay 1} \\
\hline Female pupae weight $\times$ oviposition & 0.18 & $0.0002 *$ \\
\hline Female pupae weight $\times$ egg fecundity & 0.37 & $0.0067 *$ \\
\hline Oviposition $\mathrm{x}$ egg fecundity & 0.49 & $0.0004 *$ \\
\hline \multicolumn{3}{|l|}{ Bioassay 2} \\
\hline Female pupae weight $\times$ oviposition & -0.06 & 0.6527 \\
\hline Female pupae weight $\times$ egg fecundity & -0.06 & 0.6496 \\
\hline Oviposition $\times$ egg fecundity & -0.13 & 0.6721 \\
\hline \multicolumn{3}{|l|}{ Bioassay 3} \\
\hline Female pupae weight $\times$ oviposition & 0.52 & $0.0001 *$ \\
\hline Female pupae weight $\times$ egg fecundity & 0.54 & $0.0001^{*}$ \\
\hline Oviposition $\times$ egg fecundity & 0.55 & $0.0001 *$ \\
\hline \multicolumn{3}{|l|}{ Bioassay 4} \\
\hline Female pupae weight $\times$ oviposition & 0.37 & $0.0053 *$ \\
\hline Female pupae weight $\times$ egg fecundity & 0.26 & $0.0454^{*}$ \\
\hline Oviposition $\times$ egg fecundity & 0.47 & $0.0005^{*}$ \\
\hline
\end{tabular}

*Statistically significantly $(\mathrm{P}<0.05)$

Similar results were reported by Salama \& Sharaby (1988), who observed effects of Bt galleriae on egg production and egg fecundity. Pedersen et al. (1997) and Salama et al. (1981) reported reduction of oviposition and egg fecundity to many insect species. Ramachandran et al. (1993) observed no deleterious effect of Cry1Aa protein to pupae weight of $C$. fumiferana and Hyphantria cunea, suggesting that some effect may occur according to the $B t$ toxins. This may explain the different results observed between isolates in the present study.

Some $B t$ isolates affected the biological parameters of $S$. frugiperda, mainly larval and female pupae weight, and in some instances these effects passed on to further life cycle stages affecting oviposition and egg fecundity. Results from by Glare \& O'Callagham (2000) also showed the same effect. Furthermore, according to the same authors, there are few papers available up to now with Bt kurstaki (Dipel) and further studies must be carried out due to the increasing utilization of $B t$ in pest management.

Research on entomopathogen sublethal effects may remodel the concept of pathogen efficiency. Surviving insects could have their development affected in such a way that they could become unable to cause severe dam- age to plants. Although these effects are difficult to evaluate under field conditions, they certainly occur (Glare \& O'Callagham, 2000). Less pesticides applications would be needed, decreasing cost production and increasing farmer's life quality.

\section{REFERENCES}

ABDUL-SATTAR, A.A.; WATSON, T.F. Effects of Bacillus thuringiensis var kurstaki on tabacco budworm (Lepidoptera: Noctuidae) adult and egg stage. Journal of Economic Entomology, v.75, p.596-598, 1982.

ALVES, S.B.; MORAES, S.B. Quantificação de inóculo de patógenos de insetos. In: ALVES S. B. (Ed.) Controle microbiano de insetos. 2.ed. Piracicaba: FEALQ, 1998. cap.23, p.765-778.

BOLLER, E.F.; CHAMBERS, D.L. Quality aspects of mass rearing insects. In: RIDGWAY, R. L.; VINSON, S. B. (Ed.) Biological control by argumentation of natural enemies. New York: Plenum, 1977. p.219235.

BURTON, R.L.; PERKINS, W.D. WSB, a new laboratory diet for the corn earworm and the fall armyworm. Journal of Economic Entomology, v.65, p.385-386, 1972.

GLARE, T.R.; O'CALLAGHAN, M. Bacillus thuringiensis: biology, ecology and safety. Chichester: John Wiley, 2000. 350p.

HANSEN, B.M.; SALAMITOU, S. Virulence of Bacillus thuringiensis In: CHARLES, J.F.; DELÉCLUSE, A.; NIELSEN-LE ROUX, C. (Ed.). Entomopathogenic bacteria: from laboratory to field application. Dordrecht: Kluwer Academic Publishers, 2000. p.41-64.

LEUCK, D.B.; PERKINS, W.D.A method of estimating the fall armyworm progeny reduction when evaluating control achieved host-plant resistance. Journal of Economic Entomology, v.65, p.482-483, 1972.

PEDERSEN, A.; DEDES, J.; GAUTHIER, D.; van FRANKENHUYZEN, K. Sublethal effects of Bacillus thuringiensis on the spruce budworm, Choristoneura fumiferana. Entomologia Experimentalis et Applicatta, v.83, p.253-262, 1997.

PRIEST, F.G. Biodiversity of the entomopathogenic, endospore-forming bacteria. In: CHARLES, J.F.; DELÉCLUSE, A.; NIELSEN-LE ROUX C. (Ed.) Entomopathogenic bacteria: from laboratory to field application. Dordrecht: Kluwer Academic Publishers, 2000. p.1-22.

RAMACHADRAN, R.; RAFFA, K.F.; MILLER, M.J.; ELLIS, D.D.; MCCOWN, B.H. Behavioral responses and sublethal effects of spruce budworm (Lepidoptera: Tortricidae) and fall webworm (Lepidoptera: Arctiidae) larvae to Bacillus thuringiensis Cry1Aa toxin in diet. Environmental Entomology, v.22, p.197-211, 1993.

SALAMA, H.S.; SHARABY, A.F. Effects of exposure to sublethal doses of Bacillus thuringiensis (Berl.) on the development of the greasy cutworm Agrotis ypsilon (Hufn.). Journal of Applied Entomology, v.106, p.503-511, 1988.

SALAMA, H.S.; FODA, M.S.; EL SHARABI, A.; MATTER, M.; KHALAFALLAH, M. Development of some lepidopterous cotton pests affected by exposure to sublethal levels of endotoxins of Bacillus thuringiensis for different periods. Journal of Invertebrate Pathology, v.38, p.220-229, 1981.

TAMEZ-GUERRA, P.; GALÁN-WONG, L.J.; MEDRANO- ROLDÁN, H.; GARCIA-GUTIÉRREZ, C.; RODRIGUEZ-PADILLA, C.; GOMEZFLORES, R. A.; TAMEZ-GUERRA, R.S. Bioinseticidas: su empleo, produción y comercialización en México. Ciencia UANL, v.4, p.143152,2001

Received September 24, 2004

Accepted August 12, 2005 